\title{
Hubungan Self Efficacy Dengan Perilaku Prokrastinasi Akademik Pada Mahasiswa Keperawatan Ekstensi Yang Sedang Menyusun Skripsi di STIKes Bhakti Kencana Bandung
}

\author{
Raihany Sholihatul Mukaromah ${ }^{1}$, Kristina E.Fatima Mawo ${ }^{2}$, Anggi Jamiyanti ${ }^{3}$
}

\begin{abstract}
Abstrak
Mahasiswa keperawatan tingkat akhir adalah mahasiswa yang memasuki semester akhir yang dihadapkan dengan penyusunan skripsi. Skripsi merupakan suatu persyaratan untuk menyelesaikan pendidikan dan untuk mendapatkan gelar sarjana keperawatan. Selama penyusunan skripsi mahasiswa sering menunda - nunda untuk menyelesaikannya yang sering disebut prokrastinasi akademik. Salah satu faktor yang mempengaruhi prokrastinasi akademik adalah self efficacy. Tujuan penelitian ini untuk mengetahui hubungan self efficacy dengan prokrastinasi akademik pada mahasiswa keperawatan ekstensi yang sedang menyusun skripsi di STIKes Bhakti Kencana Bandung. Jenis penelitian deskriptif korelatif menggunakan cros sectional dengan sampel sebanyak 51 mahasiswa. Menggunakan instrumen kuesioner self efficacy dan prokrastinasi akademik. Analisa data yang digunakan univariat dan bivariat dengan uji Spearmen Rank. Hasil penelitian menunjukan korelasi sebesar $\mathrm{r}=-612$ dengan signifikasi $\mathrm{p}$ - value $=0,000$. Dengan persentase self efficacy rendah 51\% dan prokrastinasi akademik tinggi 78,4\%. Ada hubungan negatif antara self efficacy dengan perilaku prokrastinasi akademik. Semakin rendah nilai self efficcay maka akan semakin tinggi nilai prokrastinasi akademik. Berdasarkan hasil penelitian diharapkan kepada prodi S1 Keperawatan untuk meningkatkan kedisiplinan dan melakukan konseling kepada mahasiswa tentang dampak dari prokrastinasi akademik sehingga dapat meningkatkan self efficacy mahasiswa..
\end{abstract}

Kata Kunci: Mahasiswa, Prokrastinasi Akademik, Self Efficacy.

\section{Abstract}

Upperclassmen of nursing students are college students of la in nursing education program who under go the proces of essay making. Essay is a requirement for finishing the education and to get nursing bachelor degree. During the essay making program, students tend to procrastinate to finish it wich often as academic procrastination. One of the factor which affect the procrastination is self efficacy.The purpose of this research is to discover the corellation of self efficcacy with academic procrastination at nursing college students of extention class who under go the essay making proces at STIKes Bhakti Kencana Bandung. The design of this research is corellative descriptive with cross sectional approach. The sample in this research are 51 students using self efficcacy and academic procrastination questionare. The data analysis used are univariate and bivariate with spearmen rank test. The result of this research showed a corellation of $r=-612$ with $0,000 p$ value significancy. The persentage of self efficacy is low with $51 \%$ and high academic procrastination with $78,4 \%$. There is a negative corellation between self efficacy with academic procrastination. The lower the self efficacy is the higher the academic procrastination are.Based on the result of the research, it is recomended for the nursing bachelor faculty to increases the discipline of the students and doing conselling about the impact of academic procrastination thus will improve the student's self efficacy.

Keywords: Academic proscratination, College students, Self efficacy 


\section{PENDAHULUAN}

Mahasiswa menurut UU No. 12 Tahun 2012 adalah seseorang yang terdaftar namanya di perguruan tinggi baik negeri maupun swasta. Mahasiswa keperawatan adalah seorang yang dipersiapkan untuk dijadikan perawat profesional di masa yang akan datang (Black, 2014). Mahasiswa keperawatan tingkat akhir adalah mahasiswa yang memasuki semester - semester akhir yang dihadapakan dengan penyusunan tugas akhir seperti skripsi.

Dalam Peraturan Menteri Pendidikan dan Kebudayaan Republik Indonesia Nomor 49 Tahun 2014 tentang Standar Nasional Pendidikan Tinggi pasal 45 mengatakan bahwa kegiatan penelitian yang dilakukan oleh mahasiswa dalam rangka melakukan tugas akhir seperti skripsi mengarah pada terpenuhinya capaian pembelajaran lulusan serta memenuhi kententuan dan peraturan di perguruan tinggi.

Berdasarkan data akademik dari BAUK STIKes Bhakti Kencana Bandung tahun 2018 didapatkan bahwa tingkat persentase kelulusan mahasiswa pada tahun 2015 sebanyak 88\%, 2016 sebanyak 87\%, 2017 sebanyak $81 \%$, sedangkan untuk kelas ekstensi persentase kelulusan tahun 2015 sebanyak 85\%, 2016 sebanyak 78\%, 2017 sebanyak 76\%. Di tahun 2018 jumlah mahasiswa reguler yang sedang menyelesaikan skripsi sebanyak 71 orang dan kelas ekstensi sebanyak 86 orang. Data dari BAUK dapat dilihat bahwa tingkat kelulusan mahasiswa kelas ekstensi megalami penurunan selama tiga tahun terakhir.

Faktor - faktor yang mempengaruhi kelulusan yang tidak tepat waktu adalah adanya penundaan tugas akhir (Fibrianti, 2009 dalam Annisa Rosni Zusya, Sari Zakiah Akhmal, 2016). Menurut Siaputra (2012) penundaan tugas akhir dapat disebabkan oleh beberapa hal, diantaranya adalah sikap kurang disiplin mahasiswa ( tidak mengikuti atau telat bimbingan skripsi sesuai dengan jadwal yang telah ditentukan), pembimbing yang sulit ditemui, tidak mendapatkan persetujuan dari dosen pembimbing (misalnya, judul skripsi tidak disetujui oleh dosen pembimbing, perbaikan yang diberikan tidak memuaskan), sulit mencari literatur terkait dengan skripsi (sulit mencari jurnal, buku referensi) dan sebagainya. Gejala perilaku menunda lebih banyak dimanifestasikan dalam dunia pendidikan yang sering disebut prokrastinasi akademik. Perilaku - perilaku yang mencirikan penundaan dalam tugas akademik dipilah dari perilaku lainnya dan dikelompokan menjadi unsur prokrastinasi akademik (Ghufron, 2012).

Prokrastinasi akademik menurut McCloskey (Ghufron, 2012) adalah kecenderungan untuk menunda nundaaktivitas yang berhubungan dengan belajar di lingkungan akademik. Menurut 
Green (Ghufron, 2012) jenis tugas yang menjadi objek prokrastinasi akademik adalah tugas yang berhubungan dengan kinerja akademik. Prokrastinasi akademik dipengaruhi oleh dua faktor, yaitu: faktor internal dan eksternal. Faktor - faktor internal tersebut, diantaranya self efficacy (AlQudah, Alsubhien, \& Heilat, 2014; Roghani, Aghahoseini, \& Yazdani, 2015; Lowinger et al, 2016) dan self control (Steel, 2007). Self efficacy merupakan keyakinan individu terhadap kemampuannya dalam mengatur dan melakukan tindakan untuk mencapai hasil tertentu (Bandura, 1997 dalam Cindy Clara $\mathrm{dkk}$, 2017). Sementara itu self control merupakan kemampuan individu untuk mengesampingkan atau mengubah reaksi batin, baik menghentikan perilaku yang tidak diingin kan maupun menahan diri untk tidak bertindak demikian (Tangney, Baumeister, \& Boone, 2004 dalam Cindy Clara dkk, 2017).

Bandura menjelaskan bahwa dalam kehidupan sehari - hari orang membuat keputusan untuk mencoba berbagai tindakan dan seberapa lama menghadapi kesulitan kesulitan. Teori Belajar Sosial mengatakan bahwa permulaan dan pengaturan transaksi dengan lingkungan, sebagian ditentukan oleh penilaian self efficacy. Self efficacy menyebabkan keterlibatan aktif dalam kegiatan, mendorong perkembangan kompetensi. Sebaliknya self efficacy yang mengarahkan individu untuk menghindari lingkungan dan kegiatan, memperlambat perkembangan potensi dan melindungi persepsi diri yang negatif dari perubahan yang membangun (Ghufron, 2012).

Bandura (dalam Ghufron, 2012) mendefinisikan Self efficacy sebagai suatu keyakinan individu mengenai kemampuan dirinya dalam melakukan tugas atau tindakan yang diperlukan untuk mencapai hasil tertentu (Ghufron, 2012). Baron dan Byrne (Ghufron,2012) mendefinisikan self efficacy sebagai evaluasi seseorang mengenai kemampuan atau kompetensi dirinya untuk melakukan suatu tugas, mencapai tujuan, dan mengatasi hambatan. Penelitian di Tehran University of Medical Sciences Faculty of Nursing and Midwifery tahun 2012 yang mengatakan bahwa jika self efficcacy meningkat maka prestasi akademik akan meningkat dan prokrastinasi akademik akan berkurang., Hasil penelitian dari Jati Ariati, Sarah A Nasution, Qonita Laras, Ade S.Fathiawati, Ellis C.Pangabean di Politeknik Kesehatan Departemen Kesehatan Semarang tahun 2107 didapatkan bahwa prokrastinasi akademik menurun karena ada emosi positif pada diri mahasiswa.

Kelulusan yang tidak tepat waktu dapat merugikan mahasiswa sendiri, terutama dari faktor pembiayaan, ketersediaan waktu dan tenaga untuk menyelesaikan skripsi (Annisa R. Zusya, Sari Z. Akhmal, 2016)). Selain itu, kelulusan tidak tepat waktu juga menjadi 
masalah bagi fakultas karena dapat mempengaruhi penilaian akreditasi (Kemenristekdikti,2017).

Dari uraian yang telah dipaparkan di atas, peneliti tertarik untuk melakukan penelitian dengan judul "Hubungan antara self efficacy dengan perilaku prokrastinasi akademik pada mahasiswa keperawatan ekstensi yang sedang menyusun skripsi di STIKes Bhakti Kencana Bandung”

\section{METODE PENELITIAN}

Jenis penelitian yang digunakan adalah penelitian korelasional dengan pendekatan kuantitatif. Penelitian korelasional adalah penelitian yang dilakukan untuk mengetahui tingkat hubungan antara dua variabel atau lebih, tanpa melakukan perubahan, tambahan, atau manipulasi terhadap data yang memang sudah ada. Sedangkan pendekatan kuantitatif adalah melakukan pengumpulan data berupa angka-angka, selanjutnya data yang telah terkumpul dianalisis (Arikunto, 2010).

Dalam penelitian ini peneliti ingin mengetahui hubungan diantara variablevariabel yang diteliti, yaitu hubungan antara self-efficacy dengan perilaku prokrastinasi akademik pada mahasiswa keperawatan tingkat akhir ekstensi yang sedang menyelesaikan skripsi di STIKes Bhakti Kencana Bandung.

Populasi dalam penelitian ini adalah semua mahasiswa keperawatan ekstensi tingkat akhir yang sedang menyusun skripsi di STIKes Bhakti Kencana Bandung sebanyak 51 orang. Sampel pada penelitian ini adalah jumlah mahasiswa ekstensi yang tidak mengikuti ujian proposal gelombang 1 dan 2 yang diadakan mulai tanggal 18 Mei sampai dengan 2 Juni 2018, yaitu sebanyak 51 sampel. Tekhnik pengampilan sampel yaitu menggunakan purpose sampling.

\section{HASIL DAN PEMBAHASAN}

1. Hasil Penelitian

a. Gambaran Self Efficacy Pada Mahasiswa Keperawatan Ekstensi Yang Sedang Menyusun Skripsi Di STIKes Bhakti Kencana Bandung.

Tabel 1. Distribusi frekuensi karakteristik self eficacy pada mahasiswa keperawatan ekstensi yang sedang menyusun skripsi di STIKes Bhakti Kencana Bandung. ( $\mathrm{n}=51$ )

\begin{tabular}{lcc}
\hline Kategori & $\begin{array}{c}\text { Frekuensi } \\
(\mathbf{f})\end{array}$ & $\begin{array}{c}\text { Persentase } \\
(\mathbf{\%})\end{array}$ \\
\hline Rendah & 26 & 51 \\
Sedang & 16 & 31.4 \\
Tinggi & 9 & 17.6 \\
\hline Total & 51 & 100 \\
\hline
\end{tabular}

Dari tabel 1 dapat diketahui data distribusi frekuensi sebagian besar self eficacy pada mahasiswa keperawatan ekstensi yang sedang menyusun skripsi di STIKes Bhakti Kencana Bandung berada pada kategori rendah yaitu sebanyak 26 mahasiswa $(51 \%)$.

b. Gambaran Prokrastinasi Akademik

Pada Mahasiswa Keperawatan Ekstensi 
Yang Sedang Menyusun Skripsi Di STIKes Bhakti Kencana Bandung.

Tabel 2. Distribusi frekuensi karakteristik prokrastinasi akademik pada mahasiswa keperawatan ekstensi yang sedang menyusun skripsi di STIKes Bhakti Kencana Bandung. $(\mathrm{n}=51)$

\begin{tabular}{lcc}
\hline Kategori & $\begin{array}{c}\text { Frekuensi } \\
\text { (f) }\end{array}$ & $\begin{array}{c}\text { Persentase } \\
(\%)\end{array}$ \\
\hline Rendah & 11 & 21.6 \\
Tinggi & 40 & 78.4 \\
\hline Total & 51 & 100 \\
\hline
\end{tabular}

Dari tabel 2 dapat diketahui data distribusi frekuensi karakteristik hampir seluruhnya prokrastinasi akademik pada mahasiswa keperawatan ekstensi yang sedang menyusun skripsi di STIKes Bhakti Kencana Bandung ada pada kategori tinggi yaitu sebanyak 40 mahasiswa $(78,4 \%)$

c. Hubungan Antara Self Efficacy

Dengan Prokrastinasi Akademik Pada

Mahasiswa Keperawatan Ekstensi

Yang Sedang Menyusun Skripsi Di

STIKes Bhakti Kencana Bandung.

Tabel 3. Hubungan Antara Self Efficacy Dengan Prokrastinasi Akademik Pada Mahasiswa Keperawatan Ekstensi Yang Sedang Menyusun Skripsi Di STIKes Bhakti Kencana Bandung

\begin{tabular}{cccc}
\hline Korelasi & $\mathrm{N}$ & Self Efficacy & $\begin{array}{c}\text { Prokrastinasi } \\
\text { Akademik }\end{array}$ \\
\hline & 51 & 1,000 & $-0,612^{*}$ \\
& & & 0,000 \\
& 51 & $-0,612^{*}$ & 1,000 \\
& 0,000 & \\
\hline
\end{tabular}

Berdasarkan analisa pada tabel 3 koefisien korelasi dari kedua variabel didapatkan hasil uji spearmen rank dengan nilai $p$-value adalah $0.000(\mathrm{p}<0.005)$. Hal ini menunjukan ada hubungan bermakna kuat dengan tidak satu arah antara self eficacy dan prokrastinasi akademik pada mahasiswa keperawatan yang sedang menyusun skripsi di STIKes Bhakti Kencana Bandung.

\section{Pembahasan}

a. Gambaran Self Efficacy Pada Mahasiswa Keperawatan Ekstensi Yang Sedang Menyusun Skripsi Di STIKes Bhakti Kencana Bandung.

Hasil penelitian didapatkan data sebagian besar responden mengalami self efficacy rendah (51 \%) sebanyak 26 mahasiswa. Menurut Bandura (dalam Ghufron, 2012) self efficacy adalah suatu keyakinan individu memgenai kemampuan dirinya dalam melakukan tugas atau tindakan yang diperlukan untuk mencapai hasil tertentu. Teori Belajar Sosial Bandura mengatakan bahwa dalam kehidupan sehari hari orang membuat keputusan untuk mencoba berbagai tindakan dan seberapa lama menghadapi kesulitan - kesulitan. Teori Belajar Sosial mengatakan bahwa permulaan dan pengaturan transaksi dengan lingkungan, sebagian ditentukan oleh self efficacy (Ghufron, 2012). Hal ini dikuatkan dengan pendapat Baron dan Byrne yang mendefinisikan self efficacy sebagai evaluasi seseorang mengenai kemampuan atau kompetensi dirinya untuk melakukan suatu tugas, mencapai tujuan, dan mengatasi hambatan (Ghufron, 2012). 
Temuan ketika penelitian didapatkan bahwa mahasiswa mengatakan mereka kesulitan mengatur tempat ketika mengerjakan skripsi tanpa adanya gangguan (55\%, kesulitan meminta masukan tentang perbaikan skripsi dari teman - teman $(52,54 \%)$ dan kurang mampu memahami penulisan dalam meyusun skripsi (52,54\%). Hal ini sesuai dengan teori Bandura (Ghufron, 2012) yang mengatakan bahwa ada tiga dimensi self efficacy yaitu Level, yaitu tingkat kesulitan yang diyakini individu, Strength tingkat kekuatan dari keyakinan dan Generality luas bidang tingkah laku. Pendapat Gist dan Mitchel (Ghufron, 2012) yang mengatakan bahwa self efficacy dapat membawa pada perilaku yang berbeda diantara individu dengan tujuan, pengatasan masalah, dan kegigihan dalam berusaha.

Menurut Teori Belajar Sosial Bandura (Ghufron, 2012) self efficacy menyebabkan keterlibatan aktif dalam kegiatan, mendorong perkembangan kompetensi. Sebaliknya self efficacy yang mengarahkan individu untuk menghindari lingkungan dan kegiatan, memperlambat perkembangan potensi dan melindungi persepsi diri yang negatif dari perubahan yang membangun.

\section{b. Gambaran Prokrastinasi Akademik} Pada Mahasiswa Keperawatan Ekstensi Yang Sedang Menyusun Skripsi Di STIKes Bhakti Kencana Bandung.
Hasil penelitian prokrastinasi akademik didapatkan hampir seluruh mahasiswa mengalami prokrastinasi akademik $(78,4 \%)$. Dari data tersebut dapat dilihat bahwa hampir semua mahasiswa melakukan penundaan dalam mengerjakan skripsi. Hal ini sesuai dengan teori McCloskey (dalam Ghufron, 2012) yang mengatakan bahawa Prokrastinasi Akademik adalah kecenderungan untuk menunda - nunda aktivitas yang berhububungan dengan belajar di lingkungan akademik. Teori Solomo dan Rothblum (dalam Ghufron, 2012) mengemukakan bahwa prokrastinasi adalah suatu kecenderungan untuk menunda dalam memulai maupun menyelesaikan kinerja secara keseluruhan untuk melakukan aktivitas lain yang tidak berguna, sehingga kinerja menjadi terlambat, tidak pernah menyelesaikan tugas tepat waktu, serta sering terlmbat dalam perkuliahan.

Selama proses penelitian, $89,70 \%$ mahasiswa mengatakan mereka melakukan penundaan mengerjakan skripsi walaupun mereka tahu bahwa skripsi adalah tugas yang penting, 88,23\% mengatakan mereka kerap membuang buang - buang waktu, 84,31 \% mengatakan mengerjakan skripsi termasuk hal yang membosankan, dan 78,92\% mengatakan ketika tidak bisa mendapatkan jalan keluar mereka akan menunda mengerjakan skripsi.

Hal ini sesuai degan teori dari Ferrari (Ghufron, 2012) yang mengatakan bahwa 
prokrastinasi termanifestasi dalam indikator atau ciri sebagai berikut, penundaan untuk memulai maupun menyelesaikan kerja pada tugas yang dihadapi, keterlambatan dalam mengerjakan tugas, kesenjangan waktu antara rencana dan kinerja aktual dan melakukan aktivitas lain yang lebih menyenangkan daripada menyelesaikan tugas yang harus dikerjakan.

\section{c. Hubungan Antara Self Efficacy} Dengan Prokrastinasi Akademik Pada Mahasiswa Keperawatan Ekstensi Yang Sedang Menyusun Skripsi Di STIKes Bhakti Kencana Bandung.

Hasil analisa data menunjukan bahwa ada hubungan bermakna kuat antara self eficacy dengan prokrastinasi akademik pada mahasiswa keperawatan yang sedang menyusun skripsi di STIKes Bhakti Kencana Bandung. Artinya semakin tinggi self eficacy maka semakin rendah prokrastinasi akademik, sebaliknya semakin tinggi prokrastinasi akademik maka semakin rendah self eficacy mahasiswa keperawatan ekstensi dalam menyusun skripi.

Hasil analisis korelasi ini mendukung hipotesis yang diajukan dalam penelitian ini, yaitu ada hubungan antara self efficacy dengan perilaku prokrastinasi akademik pada mahasiswa keperawatan ekstensi yang sedang meyusun skripsi di STIKes Bhakti Kencana Bandung. Dengan demikian, dapat dinyatakan bahwa hipotesis yang diajukan dalam penelitian ini diterima.

Hasil uji analisis Spearmen Rank didapatkan korelasi dari kedua variabel adalah $-0,612$ dengan $p$ - value adalah 0,000 $(\mathrm{p}<0,005)$. Maka diadapatkan bahwa ada hubungan bermakna bermakna kuat dengan tidak satu arah antara self efficacy dengan perilaku prokrastinasi akademik pada mahasiswa keperawatan ekstensi yang sedang menyusun skripsi di STIKes Bhakti Kencana Bandung

Berdasarkan hasil analisis dalam penelitian ini, maka dapat diketahui bahwa self efficacy merupakan salah satu faktor yang mempengaruhi prokrastinasi akademik. Penelitian yang dilakukan di Tehran University of Medical Sciences Faculty of Nursing and Midwifery tahun 2012 didapatkan bahwa hasiil uji p $(<0,001)$ sehingga jika terjadi peningkatan prokrastinasi akademik maka prestasi akademik dan self efficacy akan menurun, dan jika self efficacy meningkat maka prestasi akademik meningkat dan prokrastinasi akademik menurun.

Berdasarkan hasil temuan dilapangan sebanyak 55\% mahasiswa mengatakan kesulitan mengatur tempat untuk mengerjakan skripsi hal ini akhirnya memberikan dampak sebanyak $89,70 \%$ terhadap penundaan mengerjakan skripsi walau mahasiswa tahu bahwa skripsi adalah hal yang penting. 
Penelitian oleh Fitria dan Lukmawati tahun 2016 di STIKes Mitra Adiguna Palembang mengatakan bahwa adanya hubungan negatif antara regulasi diri dengan perilaku prokrastinasi akademik pada mahasiswa prodi DIII keperawatan dengan hasil $\mathrm{p}=0,000$, berarti $\mathrm{p}<0,01$ yang artinya ada hubungan negatif yang sangat signifikan.

Hasil penelitian dari Jati Ariati, Sarah A Nasution, Qonita Laras, Ade S.Fathiawati, Ellis C.Pangabean pada tahun 2017 di Politekhnik Kesehatan Departemen Kesehatan Semarang didapatkan prokrastinasi akademik menurun karena adanya emosi positif dalam diri mahasiswa. Dari beberapa penenelitian tersebut dapat disimpulkan bahwa semakin tinggi self eficacy maka semakin rendah prokrastinasi akademik, sebaliknya semakin tinggi prokrastinasi akademik maka semakin rendah self eficacy mahasiswa keperawatan ekstensi STIKes Bhakti Kencana Bandung dalam menyusun skripsi.

Hasil penelitian kepada 51 mahasiswa keperawatan ekstensi yang terlambat sidang proposal pada gelombang 1 dan 2 didapatkan koefisien korelasi dari kedua variabel adalah 0,612 dengan $p$-value adalah $0.000(\mathrm{p}<0.005)$. Hal ini menunjukan ada hubungan bermakna kuat dengan tidak satu arah antara self efficacy dengan perilaku prokrastinasi akademik pada mahasiswa keperawatan ekstensi yang sedang menyusun skripsi di STIKes Bhakti Kencana Bandung.
Berdasarkan uraian hasil penelitian diatas menunjukan bahwa terjadinya peningkatan prokrastinasi akademik disebabkan oleh self efficacy mahasiswa yang rendah hal ini bisa dipengaruhi oleh motivasi mahasiswa yang rendah. Hal ini sesuai dengan teori Bandura yang mengatakan bahwa keberadaan self efficacy dalam diri seseorang berdampak pada empat proses utama yaitu, kognitive, motivasional, afeksi, dan proses pemilihan.

Oleh sebab itu perlu dilakukan peningkatkan motivasi kepada mahasiwa melalui konseling dan memberikan masukan - masukan positive sehingga mahasiswa mampu mencari jalan keluar dan meningkatkan harapan. Hal ini diperkuat oleh teori Saraswati Tarigan (dalam Pieter, 2010) yang mengatakan bahwa konseling merupakan proses pemberian bantuan seseorang kepada orang lain untuk membuat keputusan atau memecahkan suatu masalah melalui pemahaman pada fakta-fakta, harapan-harapan, kebutuhan dan perasaan

\section{KESIMPULAN DAN SARAN}

\section{Kesimpulan}

Dari hasil penenelitian yang telah diuraikan pada bagian sebelumnya maka dapat ditarik kesimpulan bahwa self efficacy pada mahasiswa keperawatan ekstensi yang sedang menyusun skripsi di STIKes Bhakti Kencana Bandung berada pada kategori rendah yaitu $51 \%$. Tingkat prokrastinasi 
akademik pada mahasiswa keperawatan ekstensi yang sedang menyusun skripsi di STIKes Bhakti Kencana Bandung berada pada kategori tinggi yaitu 78,4\%. Ada hubungan negatif antara self efficcay dengan perilaku prokrastinasi akademik pada mahasiswa keperawatan ekstensi yang sedang menyusun skripsi di STIKes Bhakti Kencana Bandung, yang ditunjukan dengan nilai korelasi sebesar $-0,612$ dan $\mathrm{p}=0,000$ $\mathrm{p}<0,005)$. Hal ini menunjukkan ada hubungan bermakna kuat dengan tidak satu arah antara self efficacy dengan perilaku prokrastinasi akademik pada mahasiswa keperawatan ekstensi yang sedang menyusun skripsi di STIKes Bhakti Kencana Bandung. Artinya semakin tinggi self efficacy pada diri mahasiswa, maka akan semakin rendah prokrastinasi akademiknya. Sebaliknya, semakin rendah self efficacy pada mahasiswa, maka akan semakin tinggi perilaku prokrastinasi akademiknya.

\section{Saran}

Berdasarkan hasil penelitian yang diperoleh, maka saran yang bisa diberikan adalah:

a. Bagi Prodi S1 Keperawatan

Dengan hasil penelitian ini diharapkan dapat meningkatkan kebijakan aturan prodi terkait jadwal penyusunan skripsi sehingga mahasiswa tidak terlambat dalam proses penyusunan skripsi.

b. Bagi STIKes

Dengan adanya hasil penelitian ini diharapkan pihak kampus dapat memberikan masukan positif serta motivasi kepada mahasiswa terkait meningkatkan self efficacy demi mencegah terjadinya prokrastinasi akademik dalam proses konseling kepada mahasiswa.

\section{c. Bagi Mahasiswa}

Diharapkan dengan adanya hasil penelitian ini mahasiswa dapat mengetahui tentang self efficacy dan prokrastinasi akademik, serta dampak jika terjadi prokrastinasi akademik sehingga mahasiswa mampu meningkatkan self efficacy.

\section{d. Bagi Peneliti Selanjutnya}

Bagi peneliti selanjutnya dapat memilih variabel lain yang dianggap bisa mempengaruhi perilaku prokrastinasi akademik misalnya umur, jenis kelamin dan lingkungan dengan metode kualitatif.

1, 2, 3 STIKes Bhakti Kencana Bandung Email: Raihany290891@gmail.com

\section{DAFTAR PUSTAKA}

Alqudah, M.F., Alsubhien, A. M., \& Heilat, M. Q. A. (2014). The Relationship the academic procrastination and self efficacy among sample of King Saud University students.Journal of Educaton and Practie, 5 (16), 101 -111 Retrieved from

http://www.iiste.org/Journals/index.php/ JEP/article/view/13076/13647 diakses tanggal 2 mei 2018. 
Alwilsol. (2009). Psikologi Kepribadian. Malang: UMM Press.

Azwar S. (2018). Penyusunan Skala Psikologi. Edisi II.Cetakan XIII.Yogyakarta: Pustaka Pelajar. Malang: UMM Press.

Arikunto,S. 2010. Prosedur Suatu Pendekatan Praktik. Jakarta: Rineka Cipta.

Bandura, A. (1997) Self efficacy: The Exercise of Control. New York: Freeman and Company. Diakses tanggal 19 mei 2018.

Black, B.P. (2014). Profesional Nursing Concepts\&Challenges. Elsevier: North Carolina.Diakses tanggal 2 mei 2018

Badan Pusat Statistik Provinsi Jawa Barat. Sumber data: Kopertis Wilayah IV Jawa Barat. Diakses tanggal 28 April 2018.

Buku Panduan Penulisan dan Penyusunan Skripsi Program Studi Ners STIKes Bhakti Kencana Bandung.2018.

Elisabet W. H. (2016). Self Efficacy Pengerjaan Skripsi Prokrastinasi Akademik pada Mahasiswa Fakultas Farmasi Universitas Katolik Widya Mandala Surabaya. Jurnal Experienta Volume 4 Nomor 2. Diakses tanggal 20 April 2018

Fitriya, L. (2016). Hubungan Antara Regulasi Diri dengan Perilaku Prokrastinasi Akademik Pada Mahasiswa Sekolah Tinggi Ilmu Kesehatan (STIKes) Mitra Adiguna Palembang.Jurnal Psikologi Islami Vol.2 No.1. Diakses tanggal 4 Juni 2018.

Farouq, A. (2010). Mengupas Kiat Sukses Mengatur Waktu. Jakarta: PT Prestasi Pustakarya.

Ghufron, M.Nur dan Rina R. Cetakan ke III. 2012. Teori - Teori Psikologi. Jogjakarta: Aruzz Media.

Hana. H. F. (2015). Faktor - Faktor Yang Mempengaruhi Prokrastinasi Akademik Pada Mahasiswa Fakultas Psikologi UIN Sunan Gunung Djati Bandung. Jurnal Ilmiah Paikologi Vol 2. No. 2. Diakses tanggal 23 April 2018

Idrus, M. (2009). Metode Penelitian Ilmu Sosial. Yogyakarta: Erlangga.
Jati A, Sarah A.N, Qonita L, Ade S. F, \& Ellis C.P. An Individuan Positive Emotion Exercise: Its Influence on Self Efficacy and Procrastination of Nursing Studensts.Advances in Social Science, Education and Humanities Research, volume 133.Diakses tanggal 4 Juni 2018.

Kemeristekdikti.39/SP/HM/BKKP/IV/2017 Tentang Mutu Perguruan Tinggi Menentukan Kompetensi Kelulusan. Diakses tanggal 30 April 2018

Kuncoro, M. 2009. Metode Riset Untuk Bisnis \& Ekonomi, Edisi Ketiga, Erlangga. Jakarta.

Lee.M.H.What Predicts Your Grade Better? (Correlates of Academic Procrastination, Self Efficacy and Explanatory Style With Academic Performance. Departemen of Psychology HELP University, volume 1-1 2015. Diakses tanggal 22 Mei 2018.

Priyono, MM. (2016). Metode Penelitian Kuantitatif. Edisi Revisi. Zivatama Publishing.

Pieter.H.Z. \& Namora L.L.(2010). Pengantar Psikologi dalam Keperawatan.Cetakan ke-1. Jakarta: Kencana Prenada Media Group.

Peraturan Mendikbud . 2014. Undang Undang No. 49 tentang Standar Nasional Pendidikan Tinggi. Diakses tanggal 30 April 2018.

Robert. K\& Angelo K. Perilaku Organisasi. Jakarta: Salemba Empat 2003.

Republik Indonesia. 2003. Undang - undang No 20 tentang Pendidikan Nasional

Republik Indonesia. 2012. Undang - undang No 12 tentang Pendidikan Tinggi. Diakses pada tanggal 29 April 2018

Rasouli. F. S. (2015) A Survey of the relationship between academic procrastination, academic achievement and self efficacy in nursing students of Tehran University of Medical Sciences, 2012. Diakses dari http://tums.ac.ir/ tanggal 10 Juni 2018

Santrock, J, W. (2007). Psikologi Pendidikan. Edisi Kedua. Jakarta: Prenada Media Group. 
Siaputra, I. P. (2012). Subjective and Projective Measures of Thesis Writing procrastination: real world and the sims world. Anima Indonesians Psychological Journal, 26.Diakses tanggal 20 April 2018

Sugiyono. 2010. Metodologi Penelitian Administrasi. Jakarta: CV. Alfabeta.

Sujarweni,V. W. (2015). Statistik Untuk Kesehatan. Cetakan I. Yogyakarta. Gava Media.

Sudjana. 2009. Metode Statistika. Bandung: Tarsito.

Tuckman, B.W. 2002. APA Symposium Paper, Chicago 2002 Academic Procrastinator: Their Rationalization and Web-Course Performance. Diakses tanggal 19 Juni 2018.
Wan S.A, Arneliawati, Misrawati.(2014). Perbandingan Prokrastinasi Akademik Berdasarkan Keaktifan Dalam Organisasi Kemahasiswaan. Program Studi Ilmu Keperawatan Universitas Riau. JOM PSIK VOL 1 NO 2.Diakses tanggal 12 Juni 2018 